J. Perinat. Med. 13 (1985) 179

\section{Cimetidine as pre-anesthetic agent for cesarean section: perinatal effects on the infant, the placental transfer of cimetidine and its elimination in the infants}

\author{
N. Qvist, K. Storm, A. Holmskov
}

Department of Gynecology and Obstetrics and Department of Pediatrics, Viborg Hospital, Denmark

\section{Introduction}

One of the most frequent and most severe maternal complications in patients undergoing anesthesia in connection with cesarean section the development of a syndrome (MENDELSON's) which is characterized by bronchospasm, progressive respiratory insuffiency, hypotonia and pulmonary edema $[10,12]$. The severity of the syndrome depends on the volume and acidity of the aspirate [13]. The prevention of the syndrome has been based on reduction of the gastric content and its neutralization prior to induction of anesthesia.

Fasting and aspiration do not ensure an empty stomach. Administration of oral antacids for neutralization of the gastric contents is not advisable since aspiration of antacids causes a syndrome similar to that following aspiration of acid gastric contents [6].

Cimetidine administered prior to induction of anesthesia has been demonstrated to be effective for the neutralization of gastric contents in both non-obstetric [11] and obstetric patients [12]. The placental transfer of cimetidine and its effect, if any, on the infants are poorly understood [9]. is aspiration of acid gastric contents leading to

\section{Curriculum vitae}

NiEls QVIST was born April 7, 1950. He was graduated in 1977 from the University of Aarhus. He has published in gynecology, obstetrics, surgery and anesthesia.

Since the spring of 1984 he has been a registrar in the Surgical Department, University Hospital, Odense.

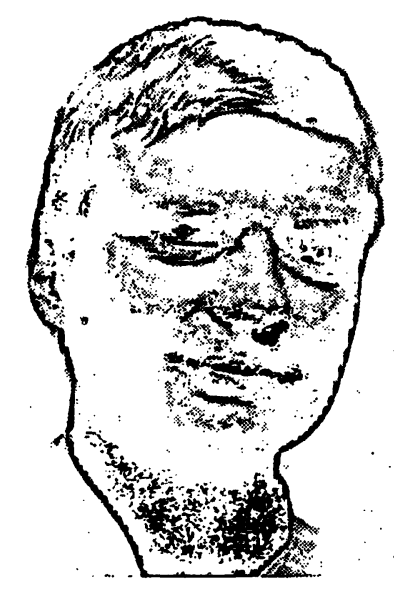

\section{Material and method}

The investigation was divided into two parts. Both parts were approved by the local ethical committee.

1. Primarily a prospective double-blind investigation comprising 39 consecutive patients undergoing cesarean section was carried out. Thirty-two patients underwent emergency cesarean section, and seven patients had elective cesarean sections. The indications appear in Tab. I. Twenty patients received cimetidine $400 \mathrm{mg}\left(100 \mathrm{mg} / \mathrm{ml}\right.$, Tagamet $\left.{ }^{(i)}\right)$ intramuscularly of a mean of 75 minutes (30-195 minutes, range) before delivery. The remaining 19 
patients were given $0.9 \% \mathrm{NaCl}$. After injection all patients were monitored with a cardiotocograph (HewletT-PACKARD, model $8030 \mathrm{~A})$. The two groups did not differ in age, weight, parity or duration of pregnancy.

Tab. I. Distribution of indications for cesarean section in both groups. In some patients there were more than one indications.

\begin{tabular}{lcc}
\hline Indications & $\mathrm{NaCl}$ & Cimetidine \\
\hline Fetal distress & 3 & 9 \\
Breech presentation & 9 & 7 \\
Placental insuffiency & 2 & 2 \\
Placental abruption & 0 & 1 \\
Cephalopelvic disproportion & 3 & 0 \\
Prior cesarean section & 1 & 0 \\
Prolonged labor & 3 & 2 \\
Others & 1 & 0 \\
\hline Number of patients & 19 & 20 \\
\hline
\end{tabular}

After delivery the infants were placed in an incubator and observed continously, particularly for heart rate and respiratory function. For birth weight below $2500 \mathrm{~g}$ or in cases of severe intrauterine asphyxia, the infants were monitored with a cardioscope. Two hours after delivery $\mathrm{K}, \mathrm{Na}, \mathrm{pH}, \mathrm{Pco}_{2}, \mathrm{HCO}_{3}^{-}$and glucose levels were determined from capillary blood samples. During the second 24-hour period of life, fasting glucose was determined, and the infants underwent a complete physical and neurological examination by a pediatrician who repeated this examination at discharge.

2. In another study, eight patients with uncomplicated pregnancies were included. These patients did not participate in the first part of the study, and they underwent elective cesarean section because of breech presentation or prior cesarean section. One to two hours prior to delivery the patients received cimetidine $400 \mathrm{mg}$ intramuscularly. At delivery. samples of maternal venous blood were obtained together with venous cord blood samples for determination of the serum cimetidine concentration (SK \& F Research
Laboratories). One, thrée and five hours after delivery blood samples from the infants were taken for determination of the serum concentration of cimetidine. The lower limits for quantitative determination of serum concentration of cimetidine was $0.03 \mathrm{mg} / \mathrm{l}$. In a few cases only $1 \mathrm{ml}$ of whole blood could be drawn from the infant, and in such cases, the lower limit of quantitation was fixed at $0.3 \mathrm{mg} / 1$.

All patients in both experiments were delivered under general anesthesia, as previously described [12]. Statistical analyses were performed using the Mann-Whitney rank-sum test for unpaired data and the $\mathrm{X}^{2}$-test.

\section{Results}

1. Altogether 20 infants were delivered in the control group, and in the cimetidine group there were 21 infants. In the control group 3 patients underwent cesarean section because of imminent intrauterine asphyxia compared to 9 patients in the cimetidine group $(0.2>\mathrm{p}>$ $0.1)$. In the cimetidine group, three infants with Apgar scores below 7 at one minute were delivered, as compared to one infant in the control group.

In the patients with abnormal cardiotocographic tracings, no alterations or new changes were observed after injection. Observed changes are listed in Tab. II. After delivery no arrhythmias, or signs of respiratory depression were observed in the infants, and the values of $\mathrm{K}$, $\mathrm{Na}, \mathrm{pH}, \mathrm{Pco}_{2}, \mathrm{HCO}_{3}^{-}$and glucose were nearly identical in the two groups (Tab. III). The differences are non-significant $(p>0.05)$. No extreme individual values were seen.

Tab. II. Abnormalities in cardiotocography in both groups. Some patients had several abnormalities.

\begin{tabular}{lcc}
\hline Cardiotocography & $\mathrm{NaCl}$ & Cimetidine \\
\hline Normal & 15 & 10 \\
Reduced variability & 2 & 5 \\
Late decelerations & 2 & 6 \\
Bradycardia & 0 & 2 \\
Absent variability & 0 & 2 \\
\hline
\end{tabular}


Tab. III. Results of capillary blood samples from the infants two hours after delivery in both groups.

\begin{tabular}{lcc}
\hline & $\mathrm{NaCl}$ & Cimetidine \\
\hline $\mathrm{Na}(\mathrm{mmol} / \mathrm{l})$ & $140 \pm 4$ & $138 \pm 5$ \\
$\mathrm{~K}(\mathrm{~mol} / \mathrm{l})$ & $4.5 \pm 0.4$ & $4.8 \pm 0.5$ \\
$\mathrm{pCO}_{2}(\mathrm{kpa})$ & $5.7 \pm 0.9$ & $5.6 \pm 0.8$ \\
$\mathrm{pH}$ & $7.37 \pm 0.04$ & $7.38 \pm 0.04$ \\
$\mathrm{HCO}_{3}^{-}$ & $23.1 \pm 1.3$ & $23.4 \pm 1.0$ \\
glucose $(\mathrm{mmol} / \mathrm{l})$ & $3.7 \pm 0.7$ & $3.4 \pm 0.7$ \\
\hline
\end{tabular}

No signs of early cerebral changes were observed in any of the infants. All infants were found to be normal during the physical and neurological examination.

2. The evaluation of placental transfer of cimetidine revealed a concentration ratio of $3: 1$ between maternal venous blood and venous cord blood (Tab. IV). In 50 per cent of the infants, there was no trace of cimetidine one hour after delivery. In one infant cimetidine was found, but only at a very low and nonquantifiable level. In the remaining three infants the concentration ratio averaged 0.7 when measured one hour after delivery as compared to the value of venous cord blood. Subsequent samples at 3 and 5 hours after delivery showed no trace of cimetidine.

None of the 8 infants presented abnormal findings after birth, and all had normal APGAR scores. The average birth weight was $3340 \mathrm{~g}$.

\section{Discussion}

Cimetidine is a histamine $\mathrm{H}_{2}$ receptor antagonist which is well known for the treatment of peptic ulcer where it blocks gastric acid secretion. Histamine $\mathrm{H}_{2}$ receptors are present in many organs including the heart and the uterus. Animal experiments have not revealed any influence of cimetidine on the contractility pattern of the uterine muscles [2] and, following a single bolus injection, no electrocardiographic changes were observed [5]; however, arrhythmias have been described following repeated doses administered to already ill and hypovolemic patients [3].

During the study, no pathological changes related to cimetidine were found in the contractility pattern of the uterus, the cardiotocographic tracings or blood samples from the infants. In the infants with low APGAR scores one minute after delivery, changes indicating severe intrauterine asphyxia were found prior to injection. The somewhat higher frequency of infants with low APGAR scores in the cimetidine group may be explained by the higher frequency of imminent fetal death as an indication for cesarean section in this group. All the infants had normal APGAR scores after 5 minutes and presented no early cerebral symptoms. To judge the condition of the newborns, we chosed the value for the APGAR score at 1 minute since this value has been found to correlate well with the values for $\mathrm{pH}$,

Tab. IV. Values for serum concentration of cimetidine (mg/l). Those results marked " are from blood samples with less than $1 \mathrm{ml}$ whole blood (quantitation limit $(0.3 \mathrm{mg} / \mathrm{l})$. ND: Cimetidine could not be detected.

\begin{tabular}{|c|c|c|c|c|c|}
\hline \multirow[t]{2}{*}{ Patient } & \multirow{2}{*}{$\begin{array}{l}\text { Maternal } \\
\text { venous blood }\end{array}$} & \multirow{2}{*}{$\begin{array}{l}\text { Venous } \\
\text { cord blood }\end{array}$} & \multicolumn{3}{|c|}{ Venous blood from infant } \\
\hline & & & $1 \mathrm{~h}$ & $2 \mathrm{~h}$ & $3 \mathrm{~h}$ \\
\hline 1 & 1.61 & 0.65 & 0.51 & $<0.03$ & ND \\
\hline 2 & 1.00 & 0.76 & $0.61^{\prime \prime}$ & $\mathrm{ND}^{\prime \prime}$ & ND" \\
\hline 3 & 2.29 & 0.63 & $0.35^{\prime \prime}$ & $\mathrm{ND}^{\prime \prime}$ & $\mathrm{ND}^{\prime \prime}$ \\
\hline 4 & 1.36 & 0.47 & ND & $\mathrm{ND}^{\prime \prime}$ & ND \\
\hline 5 & 3.44 & 1.15 & $<0.03$ & ND & ND \\
\hline 6 & 3.17 & 0.84 & ND" & $\mathrm{ND}^{\prime \prime}$ & ND" \\
\hline 7 & 3.54 & 0.89 & ND & ND & ND \\
\hline 8 & 1.86 & 0.47 & ND & $\mathrm{ND}^{\prime \prime}$ & ND" \\
\hline
\end{tabular}


$\mathrm{PcO}_{2}$ and base excess in umbilical artery blood [4]. MCGowAN [9] found no effect of cimetidine on normal labor or any perinatal effects after intravenous administration of $200 \mathrm{mg}$ of cimetidine. Others have reported similar results, although their groups were selected [8, 14].

In healthy adults most of the cimetidine is excreted unchanged in the urine, and the halflife of elimination is about 2 hours [7]. Similar conditions were observed in a premature infant who received cimetidine because of hemorrhagic gastritis [1]. In order to obtain exact values for the rate of elimination of cimetidine in the infants, we should have determined the cimetidine concentration in arterial cord blood; however, in only $50 \%$ of the infants was there detectable amounts of cimetidine one hour after delivery, and in none was detected after 2 hours. This indicates rapid elimination. ZremniaK et al. [15] found a half-life for cimetidine of 2.1 to 2.4 hours in two full-term infants.

Regarding the placental transfer of cimetidine, a fairly constant maternal/cord blood ratio of approximately $3: 1$ was found. McGowaN [9] found a ratio of $2: 1$ with very great variations.

Hence, since no changes in the course of delivery or perinatal effects on the infants were observed after administration of cimetidine, it is safe to use cimetidine as a prophylactic agent against the MENDELSON syndrome in patients undergoing cesarean section. The drug passes through the placenta at a maternal/cord blood ratio of about $3: 1$.

\section{Summary}

In a prospective randomized study of 39 consecutive cesarean sections, 20 patients received cimetidine $400 \mathrm{mg}$ intramuscularly as a pre-anesthetic, an 19 controlpatients were given $\mathrm{NaCl}$. No perinatal effects on the infants were observed by cardiotocography before delivery, and $\mathrm{K}, \mathrm{Na}, \mathrm{pH}, \mathrm{PcO}_{2}, \mathrm{HCO}_{3}^{-}$and glucose values in capillary blood were nearly identical in the two groups 2 hours after birth, the difference being non-

significant $(p>0.05)$. No respiratory effects or arrhythmias were observed.

In another study comprising 8 elective cesarean sections in patients with uncomplicated pregnancies, cimetidine was found to cross the placenta at a maternal/cord blood ratio of $3: 1$. The drug could not be detected in any of the infants 2 hours after delivery.

Keywords: Cesarean section, cimetidine, placenta, pre-anesthetic agent.

\section{Zusammenfassung}

Prämedikation mit Cimetidin bei der Sectio caesarea: perinatale Effekte, plazentarer Transfer und Elimination beim Neugeborenen

In einer prospektiven randomisierten Studie wurde bei 20 von 39 Patientinnen mit Sectio caesarea $400 \mathrm{mg}$ Cimetidin als Prämedikation i. m. verabreicht. Die Kontrollgruppe erhielt $\mathrm{NaCl}$. Cardiotokographisch ergaben sich keine Hinweise auf eine perinatale Beeinflussung. 2 Stunden post partum zeigten die $\mathrm{K}^{+}-, \mathrm{Na}^{+}-, \mathrm{pH}-, \mathrm{Pco}_{2}$, $\mathrm{HCO}_{3}^{-}$- und Blutzuckerwerte in beiden Gruppen keine signifikanten Unterschiede ( $p>0.05$ ). Respiratorische Effekte oder Arrhythmien wurden nicht beobachtet.

In einer weiteren Studie wurden 8 Patientinnen mit primär indizierter Sectio nach unkompliziertem Schwangerschaftsverlauf erfaßt. Nach dem plazentaren Transfer betrug das Konzentrationsverhältnis im mütterlichen Blut bzw. Nabelschnurblut 3:1. Zwei Stunden post partum war Cimetidin bei keinem der Neugeborenen mehr nachzuweisen.

Schlüsselwörter: Cimetidin, Plazenta, Prämedikation, Sectio caesarea.

\section{Résumé}

Cimétidine en pré-anesthésie lors des césariennes: effets périnataux sur l'enfant, transfert placentaire et élimination chez l'enfant

$\mathrm{Au}$ cours d'une étude prospective randomisée de 39 césariennes consécutives, 20 patientes ont reçu $400 \mathrm{mg}$ de cimétidine en pré-anesthésie et les contrôles ont reçu du $\mathrm{NaCl}$. Il n'a pas été observé d'effets périnataux chez les enfants sur le cardiotocogramme réalisé avant la naissance, et les valeurs sur sang capillaire du $\mathrm{K}, \mathrm{du} \mathrm{Na}$, du pH, de la $\mathrm{Pco}_{2}$, des $\mathrm{HCO}_{3}^{-}$et du glucose étaient pratiquemment identiques dans les 2 groupes après la naissance, la différence étant non significative $(p>$ 
0,05). Il n'a pas été observé d'effets respiratoires ni d'arythmies.

Dans une autre étude portant sur 8 césariennes chez des patientes ayant eu une grossesse sans complication, on a montré que la cimétidine traverse le placenta avec un rapport sang maternel/sang du cordon égal à $3 / 1$, et le médicament n'a pas pu être détecté chez les enfants 2 heures après la naissance.

Mots-clés: Césarienne, cimétidine, placenta, pre-anesthésie.

Acknowledgements: We are greatful to the SK \& F Research Laboratories, United Kingdom for determinations of the serum concentration of cimetidine.

\section{Bibliography}

[1] Aranda, J. V., E. W. Outerbridge, J. J. Schentag: Pharmacodynamics and kinetics of cimetidine in a premature newborn. Am. J. Dis. Child. 137 (1983) 1207

[2] BLYTH, D. I.: Some effects of histamine in the depolarized rat uterus. Br. J. Pharmacol. 49 (1973) 445

[3] Cohen, J., A. P. Weetman, H. J. Dargie, D. M. KRIKLER: Life-threatening arrhythmias and intravenous cimetidine. Br. Med. J. II (1979) 768

[4] Crawford, J. S., P. Davies, J. F. Pearson: Significance of the individual components of the Apgar score. Br. J. Anaesth. 45 (1973) 148

[5] ENGEL, T. R., J. C. LUCK: Histamine ${ }_{2}$ receptor antagonism by cimetidine and sinus-node function. N. Engl. J. Med. 301 (1979) 591

[6] Gibbs, C. P., D. J. Schwartz, J. W. Wynne, C. I. HooD, E. J. KUCK: Antacid pulmonary aspiration in dog. Anesthesiology 51 (1979) 380

[7] Griffiths, R., R. M. LeE, D. S. TAYLOR: Kinetics of cimetidine in man and experimental animals. In: Burland, W. L., M. A. Simkins (eds.): Cimetidine. Excerpta Medica, Amsterdam-Oxford 1977, p. 38

[8] Howe, J. P., J. Moore, W. McCaughey, J. W. DUNDEE: Effect of cimetidine in reducing intragastric acidity in patients undergoing elective cesarean section. In: Torsoli, A., P. E. Luchell, R.W. BRIMBLECOMBE (eds.): $\mathrm{H}_{2}$-antagonists. Excerpta Medica, Amsterdam-Oxford 1980, p. 174
[9] McGowan, W. A. W.: Safety of cimetidine in obstetric patients. J. R. Soc. Med. 72 (1979) 902

[10] Mendelson, C. L.: The aspiration of stomac contents into lungs during obstetric anaesthesia. Am. J. Obstet. Gynecol. 52 (1946) 191

[11] QVIST, N., M. ANDERSEN: Pre-anaesthetic cimetidine. A method of prophylaxis for Mendelson's syndrome. Ugeskr. Laeger. 142 (1980) 3369

[12] QvisT, N., K. STORM: Cimetidine preanaesthetic. A prophylactic method against Mendelson's syndrome in cesarean section. Acta Obstet. Gynecol. Scand. 62 (1983) 157

[13] Teabeaut, J. R.: Aspiration of gastric contents. An experimental study. Am. J. Pathol. 28 (1952) 51

[14] WiLsoN, J.: Effect of intravenous cimetidine on intragastric $\mathrm{pH}$ at cesarean section. In: ToRSOLI, A., P. E. LuCHELli, R. W. BRIMBLECOMBE (eds.): $\mathrm{H}_{2}$ antagonists. Excerpta Medica, Amsterdam-Oxford 1980 p. 185

[15] Ziemniak, J. A., R. J. Wynn, J. V. Aranda, B. J. ZAROWITZ, J. J. SCHENTAG: The pharmacokinetics and metabolism of cimetidine in neonates. Dev. Pharmacol. Ther. 7 (1984) 30

Received May 30, 1884. Revised August 29, 1984 Accepted September 10, 1984.

Niels Qvist, M.D.

Skovbrynet 10

DK-9500 Hobro

Denmark 


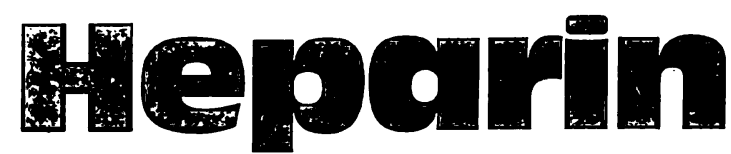

\section{New Biochemical and Medical Aspects}

Proceedings of the Symposium of the Deutsche Gesellschaft für Klinische Chemie, Titisee, Breisgau, Germany, June 29th-July 1st, 1981

Editor Irene Witt

1983. $17 \mathrm{~cm} \times 24 \mathrm{~cm}$. XVI, 372 pages. Numerous illustrations. Hardcover. DM 155,ISBN 3110086379

This book presents reviews on new aspects of heparin structure, its biosynthesis, mechanism of action and its medical usage. Each article is followed by a discussion which has been condensed in order to include only the most important aspects.
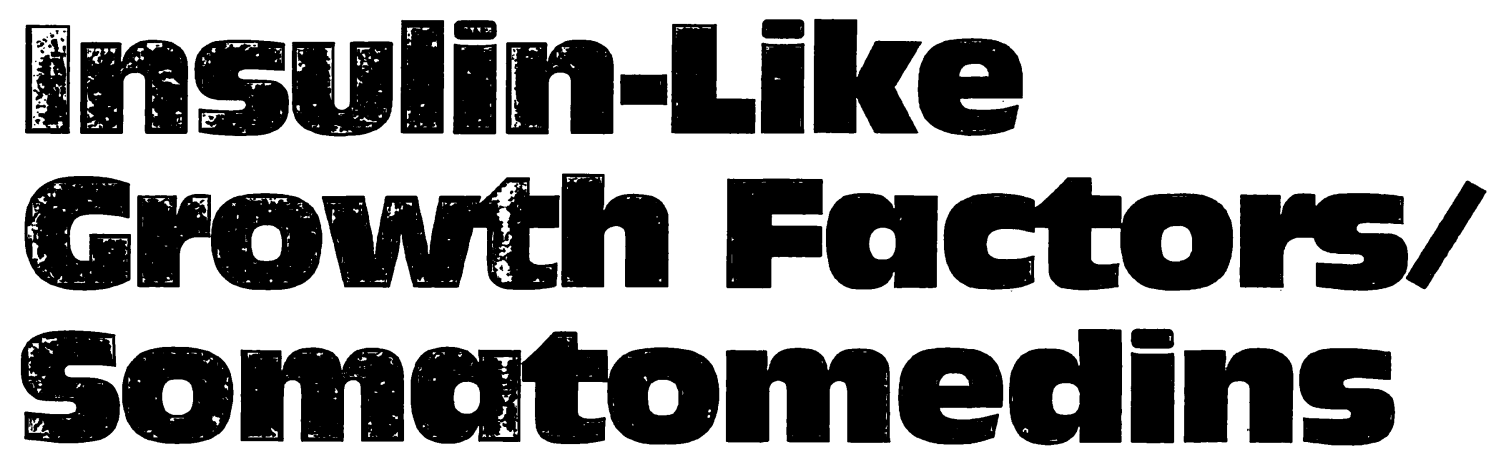

Proceedings of a Symposium on Insulin-Like Growth Factors/Somatomedins - Nairobi, Kenya, November 13-15, 1982

\section{Editor E. M. Spencer}

1983. $17 \mathrm{~cm} \times 24 \mathrm{~cm}$. XIII, 652 pages. Numerous illustrations. Hardcover. DM 240,ISBN 3110095629

This book presents an up-to-date, lucid comprehensive review of all aspects of insulin-like growth factors (somatomedins) - a family of polypeptide hormones that regulate cell growth - and their current status. These hormones mediate the growth-promoting action of growth hormone and are genetically related to insulin. Each section contains a review of our present understanding followed by the most recent research and hypotheses. The volume is compiled in such a way that it can serve as a text for insulin-like growth factors as well as presenting all the latest research information.

\section{de Gruyter · Berlin · New York}

